\title{
Implementing Inquiry Gradually with Preservice Science Teachers as Students
}

\author{
Gonca Keçeci \\ Faculty of Education, Firat University, Turkey
}

Copyright $(2017$ by authors, all rights reserved. Authors agree that this article remains permanently open access under the terms of the Creative Commons Attribution License 4.0 International License

\begin{abstract}
This study is done to have preservice science teachers chance to implement inquiry before expecting them to implement inquiry in their classrooms and to develop the preservice science teachers' inquiry skills and self-efficacy of science. The study group is composed of preservice science teachers who chose the 2nd grade Biology Laboratory course at Firat University Faculty of Education. The study group consists of 11 male and 55 female male, total 66 preservice science teachers. In the study, partially mixed concurrent equal status design is used. Qualitative data were obtained from preservice teachers' evaluation reports and quantitative data were obtained from science self-efficacy scale. The study was carried out during the fall and spring semesters for a total of eight months. Preservice teachers participated in structured, guided and open inquiry applications respectively. The preservice teachers prepared the results of their studies and shared them with their peers in the other groups. Preservice teachers have written three evaluation reports throughout the process. The application of inquiry applications respectively and the fact that the preservice teachers take part in the process like a student in these applications contributed to the science self-efficacy of the preservice teachers.
\end{abstract}

Keywords Preservice Science Teachers, Inquiry, Self-efficacy of Science

\section{Introduction}

Today, the technology is changing very rapidly. Even a newly developed product is old too soon. In this case, the need of versatile individuals that can follow the developments in science and technology has increased. The learning environments, where the students will increase the sense of wonder from the lower levels of formal education and can contribute to the development of skills and thinking habits, are required. The knowledge of significant science subjects, comprehension in everyday situations, the capability to apply that knowledge and an understanding of the characteristics of science and its interactions with society and personal life are accepted as scientific literacy [1]. To educate scientifically literate individuals that have these features has been among the goals of the curriculums [2]. Many countries have developed science education and training programs that cover these topics. Also in Turkey, the visions of 2004 science and technology curriculum and 2013 revised science curriculum is identified as to train science and technology literacy students even if the individual differences.

In order to educate the students as scientific literacy individuals, it is needed to participate in processes that they can develop skills of to think like scientists [3]. Students use inquiry to arrive at ideas and ideas that will help them to explain what they observe like a scientist. The students, especially at the primary level, do not yet have the skills to make fully developed observations, collect evidence, make predictions, test possible explanations and interpret findings unlike scientists have. Therefore, the main purpose of inquiry-based science education at primary level is to help students develop all these skills, which are defined as inquiry, research and process skills [4]. Inquiry-based learning approach is one of the approaches that can be used in developing science literate individuals [5]. Inquiry is presented as a teaching strategy and individual process skills of students [6]. Inquiry learning approach helps students to involve a process of exploring the natural or material world. Students' understanding of basic scientific ideas through direct experience with materials by consulting books, other resources, and experts can be built under the leadership of the teachers [7]. It is considered that students learn science better when they research as a scientist and use a variety of methods used by scientists [8]. The use of inquiry-based teaching in the classrooms can be provided to understand the basic facts, concepts, principles, laws, theories and to have positive attitudes towards science. Inquiry-based learning is an approach aimed at improving the students' high-level 
thinking skills and research skills that emphasize the research process rather than putting it or solving problems [9]. It is needed to implement efficient inquiry, students should have learning experiences that include all variations of the inquiry and the process should continue for one semester or one academic year [10].

For National Research Council (NRC), teachers must lead their students to develop their cognitive abilities, to search the answers of the questions like scientists and to understand the science concepts $[8,10]$. Yet, it is seen that inquiry is not routinely used in schools at all [11]. Some of the reasons for the lack of inquiry experiences of teachers may be the thought of difficulty of managing inquiry and believe inquiry education is possible only with above average students [12]. In classrooms where the inquiry based learning approach is applied, classroom management is difficult because of the students' need to wandering to explore the results of other groups and activities [13]. There is a need instructional environments are designed to promote the students' understandings about inquiry [14]. According to Llewellyn, teachers when orient inquiry in their classes should be able to organize their students well and use different questioning techniques [15]. Teachers should be a guide in inquiry activities. It is also a question of how the teacher will decide how much guidance should be given in an inquiry event [16]. It is suggested that professional development programs for science teachers need to model inquiry [8]. When it is thought that there isn't same agreement about what is inquiry, the need of the sample implementations is increased [17]. If the preservice science teachers have chance to implement inquiry before expecting them to implement inquiry in their classrooms, they can become more comfortable [18]. For Barrow, unless the preservice science teachers aren't provided an inquiry orientation during their education by science teacher preparation programs, effective inquiry will not be seen in K-12 classrooms [17].

Science and technology curriculum has been revised in Turkey. In the new regulations, inquiry based learning strategy has been adopted. According to the program, in the $3 \mathrm{rd}$ and 4 th grades structured inquiry, 5th and 6th grades guided inquiry and the 7th and 8th grades open or independent inquiry should be used. However, inquiry based teaching is defined and implemented in different ways. It is seen that neither in the world nor in Turkey research studies using an inquiry-based learning strategies are not used same methods. Even with different perceived inquiries by science researchers to question the new curriculum is a major problem of how applications will perform teachers conducting in the classes. It is not an easy for teachers not experienced about inquiry stages to create an appropriate learning environment guided and open research strategy teachers not experienced inquiry stages. If pre-service science teachers are provided inquiry applications that include structured, guided and open inquiry, they can be good inquiry practitioners, can develop self-efficacy and can be a guide, which makes their students feel like scientists. This study is done to have preservice science teachers chance to implement inquiry before expecting them to implement inquiry in their classrooms and to develop the preservice science teachers' inquiry skills and self-efficacy of science.

\section{Materials and Methods}

In the study, partially mixed concurrent equal status design is used. Leech and Onwuegbuzie have suggested that design be used in concurrent applications where both quantitative and qualitative components have equal weight [19]. Qualitative data were obtained from preservice teachers' evaluation reports and quantitative data were obtained from science self-efficacy scale.

\subsection{Study Group}

The study group is composed of preservice science teachers who chose the 2nd grade Biology Laboratory course at Firat University Faculty of Education. The study group consists of 11 male and 55 female male, total 66 preservice science teachers.

\subsection{Application}

We experienced fun, educational variations of inquiry with preservice teachers during an academic year. The study was carried out at Firat University during the fall and spring semesters for a total of eight months. In the study, the preservice science teachers formed groups of six with their peers they wanted to work with. Preservice teachers participated in structured, guided and open inquiry applications respectively. The preservice teachers prepared the results of their studies as posters after each inquiry application and shared them with their peers in the other groups.

Firstly structured inquiry activities were carried out with preservice teachers. Preservice teachers joined three structured inquiry activities. The research questions and the research steps to be done were determined by the researcher. The direction of the inquiry activities to be done was given. Preservice teachers listened to the poster presentations of their peers and evaluated their works. After the structured inquiry applications, preservice teachers wrote process evaluation reports stating their opinions and suggestions about the structured applications.

Guided inquiry was conducted with preservice teachers after structured inquiry applications. Preservice teachers joined seven guided inquiry activities. Four of the guided experiments were carried out in the first semester, three in the second semester. At this stage, preservice teachers determined the research questions by discussing them with their group of friends. Preservice teachers have been 
guided in this process. Preservice teachers have been directed specifically to identify and investigate environmental research problems. Preservice teachers shared their findings with their peers by presenting the results of their research as a poster as if they were structured inquiry activities. Preservice teachers wrote process evaluation reports stating their opinions and suggestions about the guided applications.

After the poster presentations of guided inquiry applications have been completed, preservice teachers were told that they were ready to conduct open inquiries, specifying their own research problems and conducting research processes. They were asked to identify their researches with their group mates. It was said that they will carry out one of their studies in the laboratory environment and other natural environment. It was explained to preservice teachers that a trip to Lake Hazar, a tectonic lake located near the center of Elazığ province, would be organized in order to implement open inquiry. It has been said that data collection devices (LabQuest Interface System, 3-Axis Accelerometer, Conductivity Probe, Dual-Range Force Sensor, O2 Gas Sensor, pH Sensor, Colorimeter, Magnetic Field Sensor, Light Sensor, Gas Pressure Sensor, $\mathrm{CO} 2$ Gas Sensor, Anemometer, Current Probe, Surface Temperature Probe, Temperature Probe) would be provided to preservice teachers in their research. It was explained that they would stop at three different points for observing, collecting data and making measurements. These points were determined according to the density of the settlement area. Stop points were chosen where residential areas are very dense, less dense, and where there are no residential areas. It was predicted that preservice teachers would be able to plan their studies on the environmental pollution and the relationship of settlements in open inquiry activities. However, the environment had been established for helping the viewpoints of the preservice teachers' inquiry activities, but the scientific inquiry steps had not been elucidated in which way they would conduct their studies. It was exciting to observe what preservice teachers did in open inquiry after guided inquiry practices. It was very important for the preservice teachers to personally experience the problems that their students could experience while applying the inquiry variations in their classes in the future with their students. Preservice teachers determined the topics they wanted to investigate with their group friends before the trip and chose one of them. The preservice teachers were observed at this stage without guidance. Preservice teachers completed their studies and wrote in the form of an article. They shared their results of studies with their peers as they did in other inquiry variations. Preservice teachers wrote process evaluation reports stating their opinions and suggestions about the open inquiry. Preservice teachers are also asked to summarize the variations of inquiry in the final report.

\subsection{Data Collection Tools}

Qualitative data were obtained from preservice teachers' evaluation reports and quantitative data were obtained from science self-efficacy scale.

The Biology Self-Efficacy Scale, which was prepared by Woo (1999) and adapted to Turkish by Ekici (2009)[20]. The adjusted scale was determined as 32 items and one factor. The Cronbach alpha reliability coefficient of the scales converted to science self-efficacy scale was found to be 0.946 .

Preservice teachers have written three evaluation reports throughout the process. Preservice teachers were asked that their evaluation reports should content their experiences, likes and dislikes of the applications, difficulties they had experienced in practice, their achievements and suggestions.

\subsection{Data Analyze}

Qualitative data, obtained from preservice teachers' evaluation reports, were analyzed with content analysis. Quantitative data, obtained from science self-efficacy scale, were analyzed with using the related sample $t$ test.

\section{Findings and Interpretation}

\subsection{Findings of Preservice Teachers' Science Self-Efficacy Scale Scores}

Preservice teachers' pre-test and post-test scores obtained from the science self-efficacy scale were met the normality assumption and were found to be suitable for parametric analysis. Pre-test and post-test scores were analyzed using the paired sample t-test. Findings related to the paired sample $t$ test analysis are given in Table 1 .

Table 1. The t-test Results of Science Self-Efficacy Scale Pre-Test and Post-Test Scores

\begin{tabular}{|c|c|c|c|c|c|c|c|}
\hline Measurement & $\mathrm{N}$ & $\bar{X}$ & $\mathrm{SD}$ & $\mathrm{df}$ & $\mathrm{t}$ & $\mathrm{p}$ & $\mathrm{r}$ \\
\hline Pre-test & 66 & 106.42 & 15.60 & 65 & -3.121 & .003 & .36 \\
\hline Post-test & 66 & 115.27 & 16.54 & & & & \\
\hline
\end{tabular}

The results suggest that there is a significant difference in the mean scores of science self-efficacy scale pre-test and science self-efficacy scale post-test scores. On average, participants experienced significantly greater science self-efficacy scale post-test scores $(\mathrm{M}=115.27$, $\mathrm{SE}=2.04)$ than to science self-efficacy scale pre-test scores $(\mathrm{M}=106.42, \mathrm{SE}=1.92), \mathrm{t}(65)=-3.121, \mathrm{p}<.01, \mathrm{r}$ $=.36$.

\subsection{Findings of Preservice Teachers' Evaluation Reports}

Preservice teachers have written evaluation three 
reports at the end of structured, guided and open inquiry applications. Qualitative data, obtained from preservice teachers' evaluation reports, were analyzed with content analysis. The evaluation reports of preservice teachers were examined and codes and themes were determined. The evaluation reports of preservice teachers were evaluated under three themes. The themes were determined, including the gains of the prospective teachers, the difficulties they faced and the characteristics of the inquiry steps.

\subsubsection{Analysis of Structured Inquiry Evaluation Reports}

The structured inquiry evaluation reports of preservice teachers are examined and codes are determined. Preservice teachers have the certain points in common. Themes, "gains" and "characteristics of the structured inquiry" were created according to the reports of preservice teachers. When the structured inquiry evaluation reports of preservice teachers were examined, there was no appropriate code for the difficulties encountered. The determined codes of gains theme are given in Table 2 and codes of characteristics of the structured inquiry theme are in Table 3.

Table 2. The Categories and Codes of the Theme of "Gains" of Structured Inquiry

\begin{tabular}{|c|c|c|c|}
\hline Themes & Categories & Codes & $\mathrm{f}(\%)$ \\
\hline \multirow{3}{*}{ Gains } & \multirow{2}{*}{$\begin{array}{c}\text { Contribution to } \\
\text { Personal } \\
\text { Development }\end{array}$} & $\begin{array}{l}\text { learning to prepare a } \\
\text { report }\end{array}$ & $40(61 \%)$ \\
\hline & & $\begin{array}{c}\text { the skill of using tools } \\
\text { has improved }\end{array}$ & $55(83 \%)$ \\
\hline & $\begin{array}{l}\text { Contribution to } \\
\text { Scientific } \\
\text { Process Skills }\end{array}$ & observation & $66(90 \%)$ \\
\hline
\end{tabular}

When Table 2 is examined, it is seen that the theme of "gains" is collected in two categories. These categories are contribution to personal development and contribution to scientific process skills. Preservice teachers (40\%) have learned to prepare an experiment report. Preservice teachers, as much as $90 \%$, stated that structured inquiry practices have improved their observation skills. Examples of preservice teachers (PT)' views about gains theme are as follows.

PT 64: "We learned to prepare experiment environment and to use the materials correctly."

PT 58: "I learned a lot. I learned to use a microscope and examine microscopic organisms."

PT 56: "I learned to use laboratory tools, experiment, observe and prepare reports."

PT 48: "We have done and observed many experiments I have not experienced before. But these experiments were determined by our instructor and we were not too active."
Table 3. The Codes of the Characteristics of the Structured Inquiry Theme

\begin{tabular}{|c|c|c|}
\hline Themes & Codes & $\mathrm{f}(\%)$ \\
\hline \multirow{4}{*}{$\begin{array}{c}\text { The Characteristics of the } \\
\text { Structured Inquiry }\end{array}$} & Being passive & $25(38 \%)$ \\
\cline { 2 - 3 } & Margin of error is low & $20(30 \%)$ \\
\cline { 2 - 3 } & Chance of review & $39(59 \%)$ \\
\cline { 2 - 3 } & What is wanted is done & $58(88 \%)$ \\
\hline
\end{tabular}

When Table 3 is examined, preservice teachers have defined the main characteristics of the structured inquiry applications are performing the duties that are desired by instructor, the low error rate and the chance of repeatability. Examples of preservice teachers (PT)' views about characteristics of the structured Inquiry are as follows.

PT 61: "I am very pleased that our lecturers are with us, helping us solve the problems we are experiencing with our experiments. We corrected our mistakes doing experiments again."

PT 56: "Our teachers explained to us what experiments are wanted to do and how to do it. So we did what are told to do."

PT 35: "We made experiments that are asked for. We did not have much difficulty because we had instruction form. We could have finished it without making a mistake. We learned a lot of new information."

\subsubsection{Analysis of Guided Inquiry Evaluation Reports}

The guided inquiry evaluation reports of preservice teachers are examined and codes are determined. The determined codes are collected under three themes. These themes are "gains", "challenges encountered" and "characteristics of the guided inquiry". The theme of "gains" and its categories and codes are given in Table 4.

When Table 4 is examined, it is seen that the theme of "gains" is collected in four categories. These are the categories; contribution to personal development, contribution to scientific process skills, contribution to learning and attitude change. Nine codes are collected under the personal development contribution category. Preservice teachers have indicated that guided inquiry activities have contributed to the development of their problem solving skills, pedagogical and content knowledge. Preservice teachers have also indicated that guided inquiry activities have contributed to their learning of scientific work and poster presentation. Preservice teachers indicated that they evaluated both their peers and their own deficiencies during the poster presentations. The second category of gains theme is identified as a contribution to scientific process skills. Preservice teachers stated that they were observing during guided inquiry with $39 \%$ percent. Four codes are collected under the contribution to learning category. Preservice teachers have indicated that guided inquiry help to provide useful, instructive, effective and permanent learning. Preservice teachers have felt themselves happy and willing during guided inquiry. 
Table 4. The Categories and Codes of the Theme of "Gains"

\begin{tabular}{|c|c|c|c|}
\hline Themes & Categories & Codes & $\mathrm{f}(\%)$ \\
\hline \multirow{26}{*}{ Gains } & \multirow{9}{*}{ Contribution to personal development } & Contribution to pedagogical knowledge & $17(26 \%)$ \\
\hline & & Contribution to content knowledge & $20(30 \%)$ \\
\hline & & Contribution to problem solving skills & $4(6 \%)$ \\
\hline & & Contribution to self-determination & $7(11 \%)$ \\
\hline & & Peer review & $10(15 \%)$ \\
\hline & & Learning scientific study & $6(10 \%)$ \\
\hline & & Contribution to make scientific poster presentation & $30(45 \%)$ \\
\hline & & To investigate the topics that are curious about & $5(7 \%)$ \\
\hline & & The skill of using tools has improved. & $24(36 \%)$ \\
\hline & \multirow{7}{*}{ Contribution to scientific process skills } & We designed our own experience & $19(29 \%)$ \\
\hline & & Observing & $26(39 \%)$ \\
\hline & & Setting the variables & $20(30 \%)$ \\
\hline & & Formulating hypotheses & $11(17 \%)$ \\
\hline & & We evaluated & $10(15 \%)$ \\
\hline & & Experimenting & $25(38 \%)$ \\
\hline & & We researched. & $10(15 \%)$ \\
\hline & \multirow{4}{*}{ Contribution to learning } & We got useful knowledge & $23(35 \%)$ \\
\hline & & Permanence & $12(18 \%)$ \\
\hline & & Instructive & $41(62 \%)$ \\
\hline & & Efficient learning & $3(4 \%)$ \\
\hline & \multirow{6}{*}{ Attitude change } & Being happy to learn new things & $8(12 \%)$ \\
\hline & & Being willingness to study own research & $8(12 \%)$ \\
\hline & & Wondering the result & $7(11 \%)$ \\
\hline & & To be excited & $2(3 \%)$ \\
\hline & & To love the teaching department & $4(6 \%)$ \\
\hline & & Feeling successful/ good & $6(10 \%)$ \\
\hline
\end{tabular}

Examples of preservice teachers (PT)' views about contribution to personal development category are as follows.

PT 7: "Guided inquiry contributed to love my teaching department. If God is willing, I will help my prospective students to do scientific experiments, teach them to research and evaluate the results."

PT 8: "We were able to see our own shortcomings and evaluate our friends by making poster presentations."

PT 26: "I will be able to benefit my own students in the future with the activities we do. Guided inquiry activities contributed to both my content knowledge and pedagogical knowledge."

PT 47: "I learned a lot of knowledge and techniques that I will use in my lessons as a science teacher in the future.

I learned to be open to innovations. I have realized that there are many different methods to use instead of traditional methods."

Examples of preservice teachers (PT)' views about contribution to scientific process skills category are as follows.
PT 15: "Throughout guided inquiry experiments, I have developed many skills that I will use it in my professional life. This makes me excited. What is the poster? How do I make a presentation? What is the variable? How do you write hypothesis sentences? How to interpret the results? I learned the answer to many problems like."

PT 20: "When conducting guided inquiry activities, I have learned scientific research methods, how to determine hypotheses, variables (dependent, independent, control and constant) and disciplined work."

PT 40: "I learned how to conduct a scientific study with guided inquiry; to use laboratory tools and instruments, to determine variables, to hypothesis, to solve problems, to make observations, to analyze and evaluate the results."

Examples of preservice teachers (PT)' views about contribution to learning category are as follows.

PT 24: "We did not know what to do when we first are asked to determine our research issues. We started 
searching right away using internet. We have thought that the only solution was internet. Then, we have been directed specifically to identify our own research problems by lecturers. I realized how frustrated our imagination was. I always learned to read the information and memorized. We have learned our mistakes in guided inquiry. So we learned more permanently and effectively."

PT 37: "In guided inquiry, we have solved the problems with the support of our peers and lecturers. So we learned more permanently."

Examples of preservice teachers (PT)' views about attitude change category are as follows.

PT 8: "We had more control over the experiment because we designed our own experience."

PT 12: "I was very happy observing our end result. I can't even imagine how happy scientists would be if I was so happy in such a small experiment."

PT 17: "Guided inquiry reminds me that I will be a teacher. It makes me feel important."

PT 23: "We were more willingness to do our own experiments. I said our experiments for guided inquiry because we were doing experiments what were wanted by lecturers while the structured inquiry."

"The theme of "challenges encountered" and its categories and codes are given in Table 5 .

Table 5. The Categories and Codes of the Theme of "Challenges Encountered"

\begin{tabular}{|c|c|c|c|}
\hline Themes & Categories & Codes & $\mathrm{f}(\%)$ \\
\hline \multirow{2}{*}{$\begin{array}{c}\text { Challenges } \\
\text { Encountered }\end{array}$} & $\begin{array}{c}\text { Self-sourced } \\
\text { Challenges }\end{array}$ & $\begin{array}{c}\text { Difficult } \\
\text { Experimental Error } \\
\text { (Different/Surprise } \\
\text { Result) }\end{array}$ & $6(9 \%)$ \\
\cline { 2 - 4 } & $\begin{array}{c}\text { Other } \\
\text { Sourced } \\
\text { Challenges }\end{array}$ & Team Incompatibility & $4(6 \%)$ \\
\hline
\end{tabular}

Some of the preservice teachers have indicated that they met with some difficulties in guided inquiry activities. These difficulties are categorized according to external factors and personal sources. When looking at Table 5 it is seen that preservice teachers found guided inquiry difficult because of the different results than are expected by them (24\% Experimental Error/ Surprise Results). It seems that some preservice teachers experience incompatibility because of their peers do not perform their duties and do not cooperate. It is seen that the preservice teachers complaining about team incompatibility are the same group. Teacher candidates were allowed to create new groups in open inquiry applications to address this problem. Examples of preservice teachers' views are as follows.

PT 13: "During the experiments everyone was doing their best, but I will not say the same thing to my group of friends. There was no unity in our group. In every experiment, there was a conflict within the group. No one wanted to take responsibility. Despite this, it was fun and loaded with information."

PT 31: "The result of the experiment was not what we expected. We realized that we were getting the wrong result because we used too much water. I learned to be more careful and attentive. I realized that my content knowledge was lacking and I understood that I had to improve myself."

"The theme of "Characteristics of guided inquiry" and its codes are given in Table 6 .

Table 6. The Codes of "Characteristics of Guided Inquiry" Theme

\begin{tabular}{|c|c|c|}
\hline \multirow{2}{*}{ Themes } & Codes & $\mathrm{f}(\%)$ \\
\hline \multirow{3}{*}{$\begin{array}{c}\text { The Characteristics of } \\
\text { the Guided Inquiry }\end{array}$} & Attention & $5(8 \%)$ \\
\cline { 2 - 3 } & Not to Give Up & $2(3 \%)$ \\
\cline { 2 - 3 } & Perseverance & $2(3 \%)$ \\
\cline { 2 - 3 } & Peing Open to The Criticism & $2(3 \%)$ \\
\cline { 2 - 3 } & Competition & $2(3 \%)$ \\
\cline { 2 - 3 } & Responsibility & $1(2 \%)$ \\
\cline { 2 - 3 } & & $5 \%)$ \\
\hline
\end{tabular}

When table 6 is examined, preservice teachers indicated that guided inquiry practices require attention, perseverance, patience, competition and responsibility. They also stated that it is needed not to give up from difficulties and being open to the criticism. Examples of preservice teachers' views are as follows.

PT 16: "Guided inquiry activities taught me to be attentive and hardworking and not to give up when encountered difficulties."

PT 34: "It was very nice to investigate the topics we set in group. We have all performed our duty. It was needed that to be harmonious in the group, to meet the criticism nicely and to have responsibility."

PT 39: "Guided inquiry taught me to be patience and determination, having responsibility and teamwork. These experiences I have gained will contribute to me in my professional teaching life."

\subsubsection{Analysis of Open Inquiry Evaluation Reports}

The open inquiry evaluation reports of preservice teachers are examined and codes are determined. The determined codes are collected under three themes. These themes are "gains", "challenges encountered" and "characteristics of open inquiry". The theme of "gains" is collected in four categories. These categories, contribution to personal development, contribution to scientific process skills, contribution to learning and attitude change, are gathered in codes. The theme of "gains" and its categories and codes are given in Table 7. 
Table 7. The Categories and Codes of the Theme of "Gains"

\begin{tabular}{|c|c|c|c|}
\hline Themes & Categories & Codes & $f(\%)$ \\
\hline \multirow{27}{*}{ Gains } & \multirow{9}{*}{$\begin{array}{c}\text { Contribution to personal } \\
\text { development }\end{array}$} & Contribution to pedagogical knowledge & $20(30 \%)$ \\
\hline & & Contribution to content knowledge & $20(30 \%)$ \\
\hline & & Learning scientific study & $6(10 \%)$ \\
\hline & & Contribution to problem solving skills & $1(2 \%)$ \\
\hline & & Contribution to writing articles & $20(30 \%)$ \\
\hline & & Contribution to collaboration & $36(55 \%)$ \\
\hline & & Contribution to increase interpreting ability & $5(7 \%)$ \\
\hline & & Contribution to self-determination & $3(5 \%)$ \\
\hline & & The skill of using tools has improved & $8(12 \%)$ \\
\hline & \multirow{6}{*}{$\begin{array}{l}\text { Contribution to scientific } \\
\text { process skills }\end{array}$} & We designed our own experience & $11(17 \%)$ \\
\hline & & Observing & $24(36 \%)$ \\
\hline & & Setting the variables & $8(12 \%)$ \\
\hline & & Predicting & $2(3 \%)$ \\
\hline & & Experimenting & $3(5 \%)$ \\
\hline & & Formulating hypotheses & $4(6 \%)$ \\
\hline & \multirow{4}{*}{ Contribution to learning } & Instructive & $53(80 \%)$ \\
\hline & & Efficient learning & $26(39 \%)$ \\
\hline & & Permanence & $28(42 \%)$ \\
\hline & & Analytical thinking & $4(6 \%)$ \\
\hline & \multirow{8}{*}{ Attitude change } & Enjoyable & $34(52 \%)$ \\
\hline & & Being willingness to study own research & $15(23 \%)$ \\
\hline & & Feeling successful/good & $13(20 \%)$ \\
\hline & & Wondering the result & $2(3 \%)$ \\
\hline & & Feeling like a scientist & $1(2 \%)$ \\
\hline & & Interest to science & $8(12 \%)$ \\
\hline & & Increased sense of responsibility & $8(12 \%)$ \\
\hline & & Increase self confidence & $6(10 \%)$ \\
\hline
\end{tabular}

When Table 7 is examined, it is seen that the preservice teachers describe open inquiry as instructive with a rate of $80 \%$. $30 \%$ of preservice teachers indicated that open inquiry contributed to their pedagogical and content knowledge. Preservice teachers indicated that open inquiry helped to contribute their problem solving skills, their self-image and interpreting ability. Preservice teachers indicated they have learned to work with groups and write articles. Preservice teachers have stated that scientific process skills, particularly the observation skills $(36 \%)$, have improved during open inquiry activities. Preservice teachers indicated that open inquiry activities contribute to effective, permanent learning and analytical thinking. Open inquiry helped to change of attitudes. Preservice teachers felt happy, successful and good. Some preservice teachers indicated that sense of responsibility $(12 \%)$ and their self-confidence $(10 \%)$ increased. $52 \%$ of preservice teachers said open inquiry was enjoyable. $12 \%$ of preservice teachers indicated that open inquiry improve interests toward science. Examples of preservice teachers (PT)' views about contribution to personal development category are as follows.

PT 34: "I have always been interested in laboratory lessons. We have had the opportunity to experiment with our own design with open inquiry. Our working group was very good. Everyone was doing their duty. This made group work fun. We learned writing articles by working together even if we did not know anything at all and we reported our results in the most accurately."

PT 1: "We had the opportunity to research the subjects we were curious about in the open inquiry in the real environment. Combining the lab environment with the real environment increased curiosity and enthusiasm. I will enjoy using the inquiry-based learning strategy as a teacher in the future. I think that open inquiry has important place in educating scientific literate young people. Teacher and teacher candidates should be aware of this issue."

Examples of preservice teachers (PT)' views about contribution to scientific process skills category are as follows. 
PT 4: "We designed our own experience, predicted, formulated hypotheses, set the variables, experimented and observed. We learned to evaluate and report the results of the experiment."

PT 43: "We learned to think scientifically and developed our scientific process skills in this process. We have worked more and we have used our scientific process skills more actively."

Examples of preservice teachers $(P T)^{\prime}$ views about contribution to learning category are as follows.

PT 45: "Thank you very much for teaching us such a study. I would rather use the open inquiry much more than the other experiments. Open inquiry was more tutorial, permanent and enjoyable. We learned to think from different angles."

PT 49: "We were able to act more consciously with the gains we gained from previous inquiry activities in open inquiry events. We designed our own experiments and realized the importance of moving in groups and sharing the duties. We learned to look our environment like a scientist, not ordinary. I think that the lessons that are carried out in real environment will be more lasting and more productive."

Examples of preservice teachers $(P T)^{\prime}$ views about attitude change category are as follows.

PT 52: "The experiments that we determined with joint decision and researched at real environment helped us to learn more permanently. These studies that we have worked in collaboration have increased our confidence in ourselves."

PT 53: "While our lecturers were supporting us our previous applications, they were as observers in open inquiry. We felt our responsibility and studied much more. Our self-confidence has increased. I think I will teach more effectively using open inquiry in my future teacher life."

PT 58: "We took soil and water samples from different regions around the Sivrice lake, aiming to investigate the pollution of water and soil. We did our observations. I felt like a scientist myself in this process."

"The theme of "challenges encountered" and its categories and codes are given in Table 8.

Table 8. The Categories and Codes of the Open Inquiry, Theme of "Challenges Encountered"

\begin{tabular}{|c|c|c|c|}
\hline Themes & Categories & Codes & $f(\%)$ \\
\hline \multirow{4}{*}{$\begin{array}{l}\text { Challenges } \\
\text { Encountered }\end{array}$} & \multirow{2}{*}{$\begin{array}{l}\text { Self Sourced } \\
\text { Challenges }\end{array}$} & Difficult & $2(3 \%)$ \\
\hline & & $\begin{array}{c}\text { Experimental } \\
\text { Error }\end{array}$ & $1(2 \%)$ \\
\hline & \multirow{2}{*}{$\begin{array}{l}\text { Other Sourced } \\
\text { Challenges }\end{array}$} & $\begin{array}{c}\text { Much More } \\
\text { Work }\end{array}$ & $8(12 \%)$ \\
\hline & & $\begin{array}{c}\text { Team } \\
\text { Incompatibility }\end{array}$ & $4(6 \%)$ \\
\hline
\end{tabular}

When table 8 is examined, it is seen that $12 \%$ of the preservice teachers indicate open inquiry requires more work. It is seen that 4 preservice teachers complain about team incompatibility as in guided inquiry and also in open inquiry. For two preservice teachers' view, open inquiry is difficult. However, sixteen preservice teachers complain experimental error in guided inquiry, only one preservice teacher complains in open inquiry. Examples of preservice teachers' views are as follows.

PT 29: "I am happy to do new researches but I feel very sorry when our experiments give an error. We did more researches needed to fix our errors. We had trouble because of our group mates who are insufficient of content knowledge."

Two codes have been collected under the theme of "characteristics of open inquiry". These codes are given in Table 9.

Table 9. The Codes of Theme "Characteristics of Open Inquiry" Theme

\begin{tabular}{|c|c|c|}
\hline Themes & Codes & $\mathrm{f}(\%)$ \\
\hline \multirow{2}{*}{$\begin{array}{c}\text { Characteristics of Open } \\
\text { Inquiry }\end{array}$} & Being Active & $4(6 \%)$ \\
\cline { 2 - 3 } & Real Environment & $12(18 \%)$ \\
\hline
\end{tabular}

When table 9 is examined, two characteristics of open inquiry are seen. Characteristics of open inquiry are indicated as need to be active $(6 \%)$ and opportunity to research real environment (18\%) by preservice teachers. Examples of preservice teachers' views are as follows.

PT 38: "We were able to find out by conducting experiments in the real environment in the open inquiry. To research in real environment made it more useful and permanent."

PT 10: "To learn making experiments in the real environment helped our learning be permanent."

PT 5: "We had the opportunity to go out of the laboratory and conduct experiments in real environment during open inquiry activities. We were not only doing our own design but also actively researching in the real environment."

\section{Conclusions and Recommendations}

In this study, it was aimed to find out the effect of inquiry-based learning on the preservice teachers' science self-efficacy and the views of preservice teachers about the inquiry-based learning strategy. It is thought that the preservice science teachers could be good inquiry practitioners and could be a guide, which makes their students feel like scientists. Prosperous science teachers could endeavor to assist their students in understanding and implementing scientific concepts and join in scientific inquiry [1]. This study was done to have preservice science teachers chance to implement inquiry before expecting them to implement inquiry in their classrooms. For an academic year, preservice teachers participated in 
structured, guided and open inquiry applications respectively. For the results of the science self-efficacy scale pre-test and post-test scores, it is seen that there is a significant difference in the mean scores of the scale. Preservice teachers' science self-efficacy has increased as a result of inquiry applications $(\mathrm{t}(65)=-3.121, \mathrm{p}<.01)$. Gormally, Brickman, Hallar and Armstrong found that traditional method laboratories were more effective than inquiry labs of the development of preservice teachers' self-efficacy [5]. In this study, the preservice teachers did not choose traditional laboratories because they were gradually participating in inquiry laboratories. Preservice teachers stated that they had more responsibility in inquiry laboratories and that they were able to learn effectively if they were in the process. It is not surprising that the science self-efficacy of prospective teachers who determine research problems and solutions by their own is rather than fulfilling the duties of the instructor's direction.

Preservice teachers have written three evaluation reports throughout the process. Preservice teachers were asked that their evaluation reports should content their experiences, likes and dislikes of the applications, difficulties they had experienced in practice, their achievements and suggestions. It is decided to collect them under three themes when the preservice teachers' reports of guided and open are examined. When the evaluation reports of the preservice teachers after the structured inquiry were examined, it was seen that only two themes were collected and the comments of the preservice teachers were less than the comments of guided and open inquiry evaluation reports.

The first theme was formed from the gains of the preservice teachers. When guided and open inquiry reports were examined four categories were determined under the theme of gains. These were the categories; contribution to personal development, contribution to scientific process skills, contribution to learning and attitude change. Preservice teachers have said that both structured inquiry and open inquiry contributed to their personal development. Preservice teachers indicated that guided inquiry $(n=17)$ and open inquiry $(n=20)$ contributed to the development of their pedagogical knowledge. They also said guided inquiry $(n=20)$, open inquiry $(n=20)$ contributed to the development of their content knowledge. A qualified teacher should have pedagogical knowledge that can best transfer this knowledge in addition to good content knowledge [21, 22, 23]. It is thought that the participation of the preservice teachers as students in the teaching practices based on inquiry without being taken into their professional lives will contribute. Six prospective teachers indicated that guided and open inquiry helped them to learn scientific work. Preservice teachers have difficulty directing their students if they do not know enough how to do the scientific inquiry. Modeling-centered scientific inquiry can help teachers to engage their students to science [24].
Preservice teachers also indicated that both guided and open inquiry helped to contribute their problem solving skills and their self-determination. Preservice teachers have stated that their skills of using of tools have improved. If the preservice teachers do not fully master the use of laboratory equipment, no matter how good the field knowledge is, they can be inadequate in the teaching profession. After the structured inquiry, $83 \%$ of the preservice teachers said they have improved their skills of using tools. This rate has fallen in guided and open inquiry applications. In this case it can be interpreted that the structured inquiry is more effective in the development of basic tool handling skills. Preservice teachers' awareness of their own mistakes will contribute to their becoming competent teachers. After the structured inquiry preservice teachers $(61 \%)$ said that they have learned to prepare experiment report. Preservice teachers have prepared a poster presentation in guided inquiry and have written an article in an open inquiry to share their studies. Many preservice teachers said they learned to make poster presentations and writing articles to report scientifically the results.

Preservice teachers have said that inquiry contributed to their scientific process skills. Preservice teachers, as much as $90 \%$, stated that structured inquiry practices have improved their observation skills. The proportion of preservice teachers who say observation skills have improved is $39 \%$ in guided inquiry and $36 \%$ in open inquiry. This can be interpreted in two different ways. The observation skills increased during the inquiry applications that prospective teachers participated in a sequential manner. Thus the number of preservice teachers who indicated that inquiry applications contributed to the observation skills has reduced. The other comment is that the because of structured inquiry applications are being selected by the course teacher the preservice teachers feel themselves as observers during the practice. Preservice teachers stated that their scientific process skills have developed during both the guided inquiry and open inquiry applications. Science teachers should be able to teach scientific process skills to their students [25]. Preservice teachers must have these skills in order for their students to gain scientific process skills. Participating in guided and open inquiry applications by teacher candidates will contribute to the acquisition of their scientific process skills.

Preservice teachers indicated that both open inquiry and guided inquiry activities contribute to effective and permanent learning. Preservice teachers described the open inquiry $(80 \%)$ and guided inquiry $(62 \%)$ as instructive. When the proportions are examined, it is thought that the preservice teachers find the open inquiry more instructive, permanent and effective than the guided inquiry. In open inquiry preservice teachers conducted the whole process with group members and tried to overcome the difficulties themselves. Open inquiry process, which is 
the least of the guidance, is defined more instructive by preservice teachers. This can be attributed that when they are dealing with the difficulties they are faced with doing more research and working on topics they are curious about. In addition, preservice teachers defined that guided inquiry contributed them to get useful knowledge and open inquiry contributed them to think analytical.

According to evaluation reports, guided and open inquiry has also caused the attitude change of teacher candidates. Being willingness to study own research, feeling successful/good and wondering the result are the associate attitudes of guided and open inquiry. Considering evaluation reports of open inquiry, preservice teachers indicated that sense of responsibility and their self-confidence increased. $52 \%$ of preservice teachers said open inquiry was enjoyable. $12 \%$ of preservice teachers indicated that open inquiry improves interests toward science. Some preservice teachers defined that guided inquiry contribute them to love the teaching department. This is a very important achievement. A teacher who loves his profession will be more useful to his students.

According to the evaluation reports, the second theme was determined to identify the challenges faced by preservice teachers in the inquiry process. When the structured inquiry reports were analyzed, no corresponding expression was found. It may be due to the fact that the structured inquiry process is planned by the course teacher, the prospective teachers have a procedure to follow and they can be guided if necessary. Guided and open inquiry evaluation reports, it was found appropriate to separate two categories. The categories were identified as self-sourced challenges and other sourced challenges. However, $24 \%$ of preservice teachers complain experimental error in guided inquiry because of the different results than are expected by them, only one preservice teacher complains in open inquiry. Some preservice teachers complain team incompatibility because of their peers do not perform their duties and do not cooperate. Even if preservice teachers were allowed to create new groups after guided inquiry applications to address this problem, same preservice teachers complained team incompatibility in open inquiry. Prospective teachers have also complained about overwork in open inquiry.

Preservice teachers have defined the characteristics of three different types of inquiry in their evaluation reports. Preservice teachers have defined the main characteristics of the structured inquiry applications as the low error rate, the chance of repeatability and being passive because of the duties that are desired by instructor. Preservice teachers indicated that guided inquiry practices require attention, perseverance, patience, competition and responsibility. They also stated that it is needed not to give up from difficulties and being open to the criticism. Opposite of the structured inquiry, characteristics of open inquiry are indicated as need to be active and opportunity to research real environment by preservice teachers.

Significant judgments are reached when the results of this study are generally evaluated. The application of inquiry applications in turn, and the fact that the preservice teachers take part in the process like a student in these applications contributed to the science self-efficacy of the preservice teachers. This situation appears both quantitative and qualitative. In the evaluation reports, preservice teachers defined that inquiry have contributed to their personal development, pedagogical and content knowledge. Windschitl, defines previous research experience of preservice teachers was associated with use of inquiry in the classroom [26]. So preservice teachers must participate in progressively structured inquiry, guided inquiry and open inquiry activities and use their experience in the next inquiry activities. Preservice teachers have gained more benefits than structured inquiry in guided and open inquiry. Instructional environments that are designed to promote the preservice teachers' understandings about inquiry will guide them to become successful teachers. It will be an imaginary expectation that preservice teachers who are often in structured inquiry in laboratory lessons can lead their students to guided and open inquiry when they are teachers. It is suggested that teacher education programs should give opportunities to preservice teachers to experience more guided and open inquiry.

\section{REFERENCES}

[1] Beerer,K. \& Bodzin, A.M. (2004). Promoting Inquiry-Based Science Instruction: The Validation of the Science Teacher Inquiry Rubric (STIR). Paper presented at the 2004 Association for the Education of Teachers of Science, (AETS) Annual Meeting, Nashville, TN, January 8-11

[2] Çepni, S. Bilim, Fen, Teknoloji Kavramlarının Eğitim Programlarına Yansımaları, Salih Çepni (Editör). Kuramdan Uygulamaya Fen ve Teknoloji Öğretimi. Eleventh Edition Pegem Akademi Press, Ankara, 2014.

[3] Bayır, E.B. (2008). Fen Müfredatlarındaki Yeni Yönelimler Işı̆̆ında Öğretmen Eğitimi: Sorgulayıcı Araştırma Odaklı Kimya Öğretimi. Doctoral Thesis, Gazi University Educational Sciences Institute, Ankara.

[4] Duban, N. (2008). İlköğretim Fen ve Teknoloji Dersinin Sorgulamaya Dayalı Öğrenme Yaklaşımına Göre İşlenmesi: Bir Eylem Araştırması. Doctoral Thesis, Anadolu University Educational Sciences Institute.

[5] Gormally, Cara; Brickman, Peggy; Hallar, Brittan; \& Armstrong, Norris (2009) "Effects of Inquiry-based Learning on Students' Science Literacy Skills and Confidence," International Journal for the Scholarship of Teaching and Learning: Vol. 3: No. 2, Article 16.

[6] Barman, C. (2002). Guest Editorial: How do you define inquiry? Science \& Children, 40(2), 8-9. 
[7] National Science Foundation (1997). The Challenge and Promise of K-8 Science Education Reform. Foundations: A Monograph for Professionals in Science, Mathematics, and Technology Education, 1.

[8] National Research Council (1996). National Science Education Standards. Washington, DC: National Academy of Sciences.

[9] Lim, B. (2001). Guidelines for Designing Inquiry-based Learning on the Web: Online Professional Development of Educators. PhD Thesis, Indiana University.

[10] National Research Council. Inquiry and the National Science Education Standards. USA: National Academy Press, Washington, D.C., 2000.

[11] Schwarz, C., \& Gwekwerere, Y. (2007). Using a guided inquiry and modeling instructional framework (EIMA) to support pre-service K-8 science teaching. Science Education, 91(1), 158-186.

[12] Windschitl, M. (2002). Inquiry projects in science teacher education: What can investigative experiences reveal about teacher thinking and eventual classroom practice? Science Education, 87(1), 112-143.

[13] Tatar, N. (2006). İlköğretim Fen Eğitiminde Araştırmaya Dayalı Öğrenme Yaklaşımının Bilimsel Süreç Becerilerine, Akademik Başarıya ve Tutuma Etkisi. PhD Thesis, Gazi University Institute of Educational Sciences, Ankara.

[14] Crawford, B.A (2000). Embracing the Essence of Inquiry: New Roles for Science Teachers. Journal of Research in Science Teaching, 37(9), 916-937.

[15] Llewellyn, D. (2002). Inquiry within: Implementing inquiry based science standards. Thousand Oaks: Corwin.

[16] Ulu, C. (2011). Fen öğretiminde araştırma sorgulamaya dayalı bilim yazma aracı kullanımının kavramsal anlama, bilimsel süreç ve üstbiliş becerilerine etkisi. (Unpublished doctoral thesis). Marmara University, İstanbul. Obtained from the database of the National Thesis Center. (Tez no: 289645)

[17] Barrow, L.H. (2006). A Brief History of Inquiry: From Dewey to Standards. Journal of Science Teacher Education, 17:265-278.

[18] Eick, C.J., \& Reed, C.J. (2002). What makes an inquiry oriented science teacher? The influence of learning histories on student teacher role identity and practice. Science Education, 86(3), 401-416.

[19] Leech, N.L. \& Onwuegbuzie, A.J. (2009). "A typology of mixed methods research designs". Qual Quant. 43, 265-275.

[20] Ekici, G. (2009). Biyoloji öz-yeterlik ölçeğinin Türkçe’ye uyarlanması. Kastamonu Education Journal, 17 (1), 11-124.

[21] Feiman-Nemser, S., \& Buchman, M. (1987). When is student teaching teacher education? Teaching and Teacher Education, 3, 255-273.

[22] Shulman, L.S. (1986). Those who understand: Knowledge growth in teaching. Educational Researcher, 15(2), 4-14.

[23] Shulman, L.S. (1987). Knowledge and teaching: Foundations of the new reform. Harvard Educational Review, 57(1), 1-22.

[24] Schwarz, C. (2009). Developing preservice elementary teachers' knowledge and practices through modeling centered scientific inquiry. Science Education, 93(4), 720-744.

[25] Chabalengula, V.M., Mumba, F., \& Mbewe, S. (2012). How pre-service teachers' understand and perform science process skills. Eurasia Journal of Mathematics, Science \& Technology Education, 8(3), 167-176.

[26] . Windschitl, M. (2000). Pre-Service Science Teachers and the Independent Inquiry Experience. 18p; Paper presented at the Annual Meeting of the American Educational Research Association (New Orleans, LA, April 24-28, 2000). 